J. Product. \& Dev., 23(1): 85-98(2018)

\title{
FUNCTIONAL ANALYSIS OF INTRONS FOR THEIR EFFECT ON TRANSGENE EXPRESSION IN PLANT
}

\author{
Yehia A. Khidr' and Mahmoud I. Nasr ${ }^{2}$ \\ 1 Plant Biotechnology Department, Genetic Engineering and Biotechnology \\ Research Institute, Sadat City University, Egypt \\ 2 Molecular Biol85ogy Department, Genetic Engineering and Biotechnology \\ Research Institute, Sadat City University, Egypt.
}

\section{ABSTRACT}

Most plant genes contain intervening sequences known as introns that are found in nearly all plant genes and they are transcribed into pre-mRNA, the later will be removed by splicing machinery. Proteins are encoded by exons which separated by intron segments while the noncoding exons are conserved in the mature transcript. In this study, level of spliced and non-spliced introns was measured in transgenic Nicotiana tabacum lines expressing gusint-gfpint fusion gene controlled by the CaMV $35 S$ promoter. Transcription analysis of the transgenes was performed by (RT)-PCR. All transcripts of transgenic lines generated two different length of fragments for gfp and gus genes.

The results indicated that the gene expression of transcripts (without intron) in which their intron was spliced out, was higher than those of non-spliced transcript (with intron) in which the intron was maintained i.e. the both introns inside gus and gfp were partially and not completely spliced out of the transcripts. Furthermore, the relative quantifications of band intensity of gfp transcripts revealed that the percentage of non-spliced transcripts compared to the housekeeping gene, elongation factor 1-alpha (efla) using different amplification cycles (25, 30, 35 and 40) was $23.3 \%, 28.3 \%, 21.7 \%$ and $20 \%$ respectively and the percentage of spliced transcripts was $76.7 \%$, $71.7 \%, 78.3 \%$ and $80 \%$ in that order. While, the proportion of gus transcripts revealed that the non-spliced transcripts were $34.2 \%, 15.7 \%$, $12.8 \%$ and $16.3 \%$ and the spliced was $65.8 \%, 84.3 \%, 87.2 \%$, and 80 $\%$ at 25, 30, 35 and 40 cycles respectively.

Conclusively, in the present study, the expression of gus and gfp genes might linked tothe process of splicing and not to a particular intron sequence or the partial splicing may due to splicing signals within the 
sequences of the both introns. In conclusion, in spite of the incomplete splicing of the IV2 second intron of the potato ST-LS-1 gene and fristintron of a castor bean gene for catalase, the expression of gus and gfp genes was not affected. Where, it was ranged from $71.7 \%$ to $80 \%$ and from 65.8 to 87.2 for the gus and gfp, respectively in the spliced introns. Therefore, the expression of the non-spliced gus and gfp introns was much lower than those of splicedones.

Keywords: Intron, Splicing, Transgene, Gene Expression, Transgenic Plants, Gus and GFP gene.

\section{INTRODUCTION}

Introns are intervening DNA sequences largely distributed throughout gene coding regions in eukaryotes. All the DNA coding for a protein would be continuous in the genes of prokaryotes. Whereas, in eukaryotic cells the encoding DNA is typically discontinuous: stretches of encoding DNA (exons) are interspersed with long stretches of non-encoding DNA (introns). After the DNA is transcribed into pre-mRNA the introns are edited out from the nascent mRNA in a multiple-step process collectively called splicing before its translation into protein. Although introns have sometimes been loosely called "junk DNA," the fact that they are so common and have been preserved during evolution leads many researchers to believe that they serve some function. Introns were incorporating into plasmid vectors to eliminate the expression of certain proteins in bacterial cells (Ohta et al, 1990; Johnson et al., 2005), to increase expression of transgene in transgenic plants (Bartlett et al., 2009), to make a hairpin linker in RNAi vectors (Wesley et al., 2001), or to study the splicing mechanisms of plants (Rose, 2004).

Many reporter genes used for plant transformation are expressed in bacterial cells (Vancanneyt et al., 1990), and it could take several months to prevent Agrobacterium from plant tissues (Barghchi., 1995). Consequently, it is intricate to visualize the early stages of transgene expression with confidence that the observed signal derives from plant cells rather than from Agrobacterium. On the other hand, the expression of transgene in bacterial cell should be prevented by the presence of an intron whereas allowing the normal expression in plants. Preferably, the used intron should have a number of stop codons to avoid translation of unprocessed mRNA in bacterial cells, and it should be effectively removed by the splicing mechanism in plant nuclei. Similar splice junctions are excited in the plant and animal introns. Generally, 
plant introns are rich in AT with an average length of $250 \mathrm{bp}$ (McCullough et al., 1993). The intron two of the potato ST-LS1 gene (Eckes et al, 1986), is a model plant intron with an 80\% AT content with a sequence length of $189 \mathrm{bp}$, typical splice junctions, and manifold stop codons in all translational reading frames. Vancanneyt et al. (1990) produced the intron PIV2 from the second intron of ST-LS1 by changing the internal splice borders to match the consensus plant intron sequence and cloning it into the bacterial gus gene. Transcripts of the produced gus-int gene are spliced efficiently in Arabidopsis (Vancanneyt et al., 1990), tobacco (Rempel and Nelson., 1995), and maize (Narasimhulu et al., 1996).

The modified castor bean catalase intron, which is derived from the first intron of the castor bean catalase gene CAT-1, is the most widely used plant introns. It was first characterized and used by Ohta et al., (1990) as an insertion into the coding sequence of the gus reporter gene to prevent its expression in Agrobacterium cells. Expression level of transgene can be influenced by characteristics and sequence of the intron used, the location at which the transgene is inserted and orientation of the intron in the transcript, the nature of the other sequences in the construct, the cell-type and species in which the construct is expressed (Bourdon et al., 2001; Vain et al., 1996). Introns have been found to elevate mRNA accumulation in a wide range of eukaryotes. However, not all introns affect gene expression, and direct testing is currently the only way to identify stimulatory introns. Therefore, this work was conducted to investigate the effectiveness of the commonly used introns, the intron 1 of the catalase gene (cat) derived from the dicotyledonous species castor bean (Tanaka et al., 1990) and IV2 second intron of the potato ST-LS1 gene (Vancanneyt et al., 1990)] in the ability of their splicing in relation to transgene expression level in plant with the most commonly employed reporter genes ( $g u s$ and $g f p$ ) in transformation experiments in plants.

\section{MATERIALS AND METHODS}

\section{Construction of Gus-intron-Gus-GFP-intron-GFP fusion}

The Gusint (gus gene with the second intron (IV2) of the potato ST- LS1 gene) was incised from the binary vector pPBgus (Fig. 1-A left) by digestion with restriction enzymes (fermentas) Sst I at the nucleotide 430 and Sma I at the nucleotide 2502 to generate a fragment of 2073 bps. The generated fragment was cut from the agarose gel and purified with MEGAquick-spinTM Total Fragment DNA Purification Kit as described by the manufacturer instruction manual, $5 \mu 1$ 
of the purified fragment was loaded on 1\% agarose gel (Fig. 1-C). DNA Pol I, Large (Klenow) fragment was used to remove the 3' overhangs of Sst I am cutting. The binary plasmid pKBgfp (Fig. 1-A right), was linearized with Nco I at 1148 site generating 5' overhangs. Generated 5' overhangs of the pKBgfp was degraded by Mung bean Nuclease. Then, the purified Gusint fragment was fused to CATgfp in the plasmid pKBgfp using T4 DNA ligase enzyme producing a new T-DNA containing Gus-int-Gus:GFP-int-GFP fusion gene driven by a double 35S promoter of Cauliflower mosaic virus (CaMV 35S) (Odell et al., 1985 ) and terminated by the $35 \mathrm{~S}$ of CaMV in addition to the bar gene regulated by nopaline synthase (nos) gene (Depickeret al, 1982) and nos terminator (Fig. 1C). The new generated binary vector was introduced into Agrobacterium tumefaciens, LBA4404 strain using the freeze-thaw method described by An et al, (1988).

\section{Plant material and generation of transgenic plants}

Plant transformation was performed as described by Khidr and Nasr (2012). In brief, Leaf discs of in vitro grown Nicotiana tabacum cv. Xanthi plants were incubated with Agrobacterium for 2 days at $25^{\circ} \mathrm{C}$ on MS medium (Murashige and Skoog, 1962) supplemented with $1 \mathrm{mg} / \mathrm{L}$ BAP and $0.1 \mathrm{~g} / \mathrm{L}$ NAA. The explants were transferred onto the same medium with $500 \mathrm{mg} / \mathrm{L}$ Carbenicillin, $5 \mathrm{mg} / \mathrm{l}$ phosphinothricin (PPT). The explants were sub- cultured every three to four weeks on fresh medium until callus and shoots began to form (6-8 weeks). Developed shoots were individually separated and transferred onto hormone free media. Regenerated plantlets with roots were transferred to soil.

\section{RNA isolation and gene expression analysis by RT-PCR}

Total RNA was extracted from $100 \mathrm{mg}$ leaf tissues of putative transgenic lines using RNeasy Plant Mini Kit (Qiagen, Germany). The total RNA (1 $\mu \mathrm{g}$ ) was used for reverse transcribed at $42 \mathrm{C}^{\circ}$ using RevertAid ${ }^{\mathrm{TM}}$ First Strand cDNA Synthesis Kit. The generated cDNA was used as a template for PCR. The cDNA-PCR was performed using the suitable primer pairs listed in Table 1. The PCR reaction was performed in $25 \mu \mathrm{l}$ containing $50 \mathrm{ng}$ of template DNA, 1× DreamTaq $^{\mathrm{TM}}$ buffer, $0.2 \mathrm{mM}$ dNTPs, $0.5 \mu \mathrm{M}$ of each primer and 0.5 -unit DreamTaq ${ }^{\mathrm{TM}}$ DNA polymerase. The PCR condition was performed as follows: Initial denaturation at $95^{\circ} \mathrm{C}$ for $30 \mathrm{~s}$, followed by 30 cycles of denaturation (94 
Table 1: Primers used for molecular evaluation of the intron splicing

\begin{tabular}{|c|c|c|c|}
\hline Primer & Sequence $5^{\prime}>3^{\prime}$ & Annealing $\left[{ }^{\circ} \mathrm{C}\right]$ & $\begin{array}{c}\text { Amplified size inbp } \\
\text { mRNA }\end{array}$ \\
\hline Gfpintron(+) & $\begin{array}{l}\mathrm{F}: \text { :ggcttcctccggatctaagg } \\
\mathrm{R}^{+}: \text {gatctggatacctgtaactatca }\end{array}$ & 60 & 429 \\
\hline Gfp-intron(-) & $\begin{array}{l}F \text { :ggcttcctccggatctaagg } \\
\text { R1: catatgatctggataccttgaa }\end{array}$ & 64 & 244 \\
\hline Gus intron $^{(+)}$ & $\begin{array}{l}\mathrm{F}(+): \text { ttctaatatatgaccaagc } \\
\mathrm{R} \text { :ggcaataacatacggcgtga }\end{array}$ & 55 & 300 \\
\hline Gus-intron(-) & $\begin{array}{l}\text { F 1:cgatcagttcgccgatgcagatat } \\
\text { R :ggcaataacatacggcgtga }\end{array}$ & 58 & 112 \\
\hline $\mathrm{EF} 1 \alpha$ & $\begin{array}{l}\mathrm{F} \text { :tactggacatcacaggctgac } \\
\mathrm{R} \text { :aatggaagatcaagcctcagaa }\end{array}$ & 58 & 700 \\
\hline
\end{tabular}

$(+)$ : Primer is inside the intron.

${ }^{\circ} \mathrm{C}$ for $\left.10 \mathrm{~s}\right)$, annealing $\left(55^{\circ} \mathrm{C}\right.$ to $64^{\circ} \mathrm{C}$ for $\left.30 \mathrm{~s}\right)$ and extension $\left(72{ }^{\circ} \mathrm{C}\right.$ for $\left.1 \mathrm{~min}\right)$ and a final extension at $72{ }^{\circ} \mathrm{C}$ for $7 \mathrm{~min}$ (Table 1 ).

\section{Relative quantification of band intensity}

Quantification of band intensity was performed using semiquantification RT-PCR at different amplification cycles, 25, 30, 35 and 40. The PCR reaction and condition were carried out as described above. Transcription level (band abundance) was carried out using Image Lab 3 software to measure transcripts of spliced introns and non-spliced introns in comparison to the transcription of the housekeeping gene, elongation factor $1-\alpha(E F 1-\alpha)$ as an internal control.

\section{GFP-Intron sequences}

ggagcaggtgctggagcaatgtgaagagttgtttactggagttgtccctattcttgtcgaactcgatggtgacgtgaacgga cataaattttcagtgagtggtgagggagagggtgatgctacctacggaaagttgaccctcaaatttatctgtactacaggtaa acttccagttcettggecaactctcgtgacaaccttcacttatggagttcaatgcttttcaaggtaaatttctagttttctccttca ttttcttggttaggaccctttctcttttattttttgagctttgatctttctttaaactgatctatttttaattgattggttatggtgtaaa tattacatagctttaactgataatctgattactttatttcgtgtgtctatgatgatgatgatagttacaggtatccagatcatatg aagaggcacgacttcttcaaatctgctatgcctgagggttatgtgcaagaaagaaccatctctttcaaggacgacggaaatt ataaaaccagagctgaagttaagtttgaaggtgatactttggtcaacaggatcgagttgaaaggaattgatttcaaagaaga tggtaatattcttggacacaagctggagtacaactataatagtcataatgtttacattactgctgataaacagaagaacggtat caaggcaaactttaaaattagacataacatcgaagatggatctgtgcagttggctgaccattaccaacagaatacacctatt ggtgatggaccagttcttctcctgacaatcactacttgtcaacccaaagtgctctttctaaagatccaaatgagaagagaga tcacatggtgctttggagttcgttacagcagcaggtatcactcatggaatggatgaactttataagt

GFP gene containing the first intron of the catalase gene (cat) shown the primer binding position as an example.The gray color - represents the $g f p$ sequences, without background color - represents the castor bean intron (190 bp), the underline white and black letters - represents the primer binding sequences. 
GFPInt_F 5'-ggcttcctccggatctaagg-3'

GFPInt_R 5'-gatctggatacctgtaactatca-3'

GFPInt_R1 5'-catatgatctggataccttgaaaagc-3'

\section{RESULT AND DISCUSSION}

\section{Molecular investigation of transgene-intron expression}

\section{RT-PCR analysis}

Transcription analysis was examined on RNA of six putative transgenic lines by (RT)-PCR with primer pair designed to amplify the connection region of the exon-intron sites within the $g u s$ and $g f p$ sequences to verify the transcription of these reporter genes and to evaluate the splicing percentage of these introns and their effect on the expression of both the $g f p$ and gus genes. Results on gus gene sequences showed two transcript lengths, the first one was un-spliced fragment sized $300 \mathrm{bp}$ in Fig. (2A) and the second with a spliced transcript of $112 \mathrm{bp}$ in length without the IV2 intron Fig. (2B). Furthermore, the transcription level of the unspliced gus-intron differed within the transgenic lines where, it was high with the samples 2 and 4 moderate in samples 3 and 6 , and faint with samples 1 and 5 (Fig 2A). Moreover, the transcription of the gus gene varied within the spliced transcript in transgenic lines where, it was high in samples 1, 2, 3 and 4, and moderate in the samples 5 and 6 (Fig. 2B). On the other hand, transcription of the $g f p$ gene followed the same pattern with two different lengths of transcripts.

The first one was un-spliced fragment (429 bp) in size (Fig. 3A) and the second with a spliced transcript of $244 \mathrm{bp}$ in length without the Catintron (Fig. 3B). Despite the products were detected in all samples by RTPCR, the transcript varied in their level within the un-spliced and within the spliced $g f p$ gene where, it was high with the samples 2, 3 and 4 and faint with lines 1, 5 and 6 in the un-spliced $g f p$ transcript (Fig. 3A). In addition, it was high in the samples 1, 2, 3 and 4, and moderate with the sample 5 and 6 in the spliced $g f p$ transcript (Fig. 3B). In addition to the effect of introns in gene expression, these variations in the expression within and between spliced and un-spliced transgene might be also contributed to the site of integration, the transgene copy numbers, mutation of transgenes and epigenetic or gene silencing (Hobbs, et al., 1990; Fladung, 1999; Maqbool and Christou, 1999). Individually or collectively, the transcription of spliced transcripts of the gus and $g f p$ genes exhibited higher level than those of non-spliced one. 


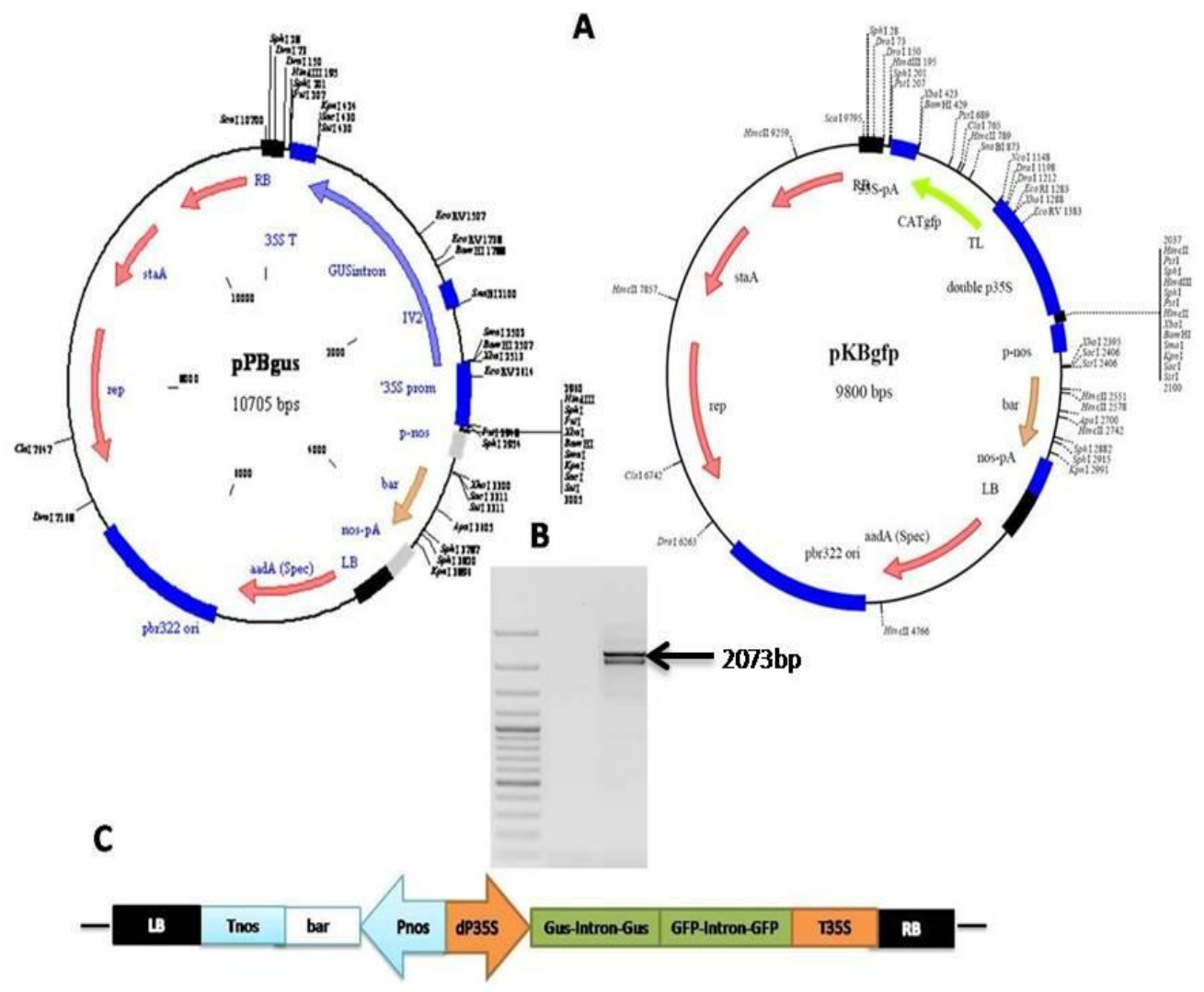

Figure 1:Construction steps of gus-gfp fusion genes containing intron. A, Binary plasmids used for the construction gus-gfp fusion; B, Digested and purified fragment (2073bps) of Gus gene containing IV2 intron with restriction enzymes SstI at position $430 \mathrm{bp}$ and SmaI at position 2502 bp gene along with Gene Ruler ${ }^{\mathrm{TM}} 100 \mathrm{bp}$ DNA Ladder Plus starting from $100 \mathrm{bp}$ to $3000 \mathrm{bp}$; C, Schematic representation of T-DNA construction. LB and RB, T-DNA left and right border sequences; Pnosand T-nos, promoter and terminator sequences of the nopaline synthase gene; bar, bar selectable marker gene; P-35S and T-35S, promoter and terminator sequences of the $35 S$ Cauliflower mosaic virus gene; Gus-Intron-Gus, reporter gene has IV2 second intron of the potato ST-LS1 gene (Vancanneytet al., 1990; GFP-Intron- GFP, reporter gene of green florescent protein has Cat-int, frist intron of a castor bean gene for catalase. 


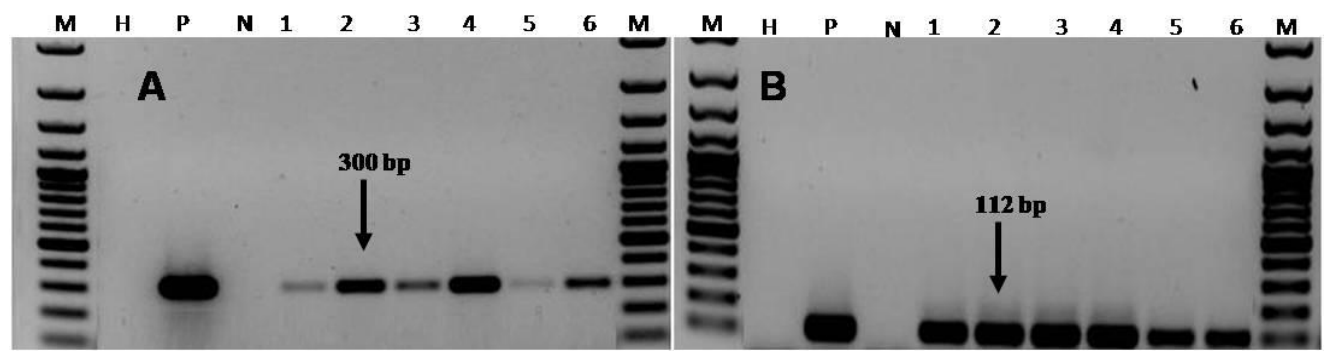

Figure 2: RT-PCR for detection of incomplete splicing of IV2-int, the second intron of the potato $S T$-LS1 gene $\mathbf{C}$, unspliced intron inside gus with a fragment size of $300 \mathrm{bp}$. $\mathbf{A}$, unspliced transcript of the gus gene with a fragment size of $300 \mathrm{bp}$. B, spliced gus gene with a fragment size of 112 bp. M, 100 bp Gene Ruler100 bp DNA Ladder Plus started with $100 \mathrm{bp}$ and ended with $3000 \mathrm{bp} ; \mathbf{H}, \mathrm{H}_{2} \mathrm{O}$ as negative control; P, plasmid DNA as positive control; N, non-transgenic plant; 1-6, transgenic lines.

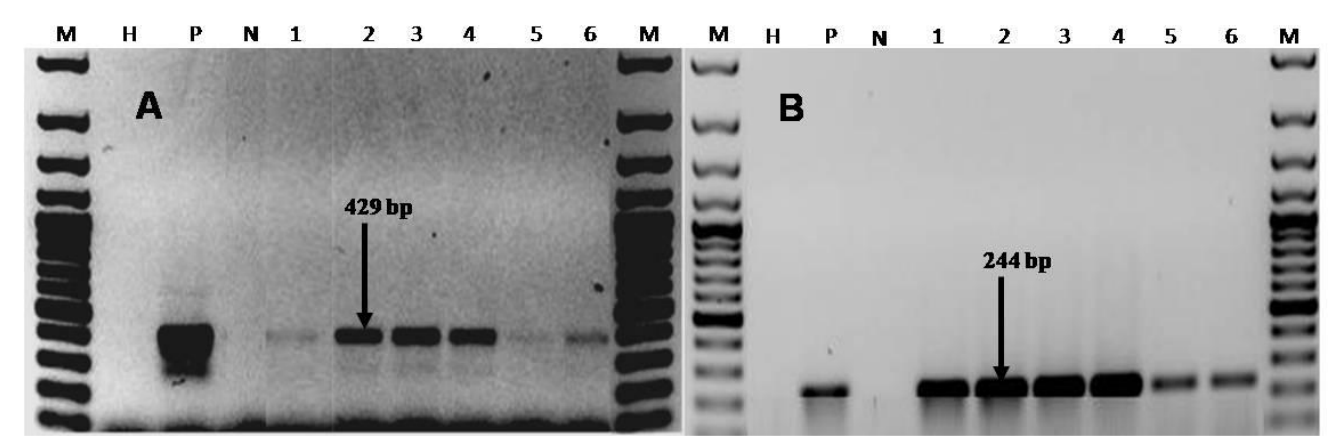

Figure 3: RT-PCR for detection of incomplete splicing of Cat-int, the frist intron of a castor bean gene for catalase within the $g f p$ transgene in transgenic Nicotiana tabacum. A, unspliced transcript of the $g f p$ gene with a fragment size of $429 \mathrm{bp}$. B, spliced $g f p$ gene with a fragment size of 244bp. M, 100 bp Gene Ruler100 bp DNA Ladder Plus started with100 bp and ended with 3000 bp; $\mathrm{H}, \mathrm{H}_{2} \mathrm{O}$ as negative control; P, plasmid DNA as positive control; N, non-transgenic plant; 1-6, transgenic lines.

\section{Semi-quantification RT-PCR of spliced and non-spliced transgenes}

The transcript level of spliced and un-spliced transgenes ( $g u s$ and $g f p$ ) was measured in comparison to the internal control of elongation factor 1- $\alpha$ (EF1$\alpha$ ) using semi-quantification RT-PCR at different amplification cycles, 25, 30, 35 and 40, and the band intensity was quantified using the gel Image Lab 3. The results of relative quantification for band intensity of the gus transcripts 
Table 2. Relative quantification of transcripts of spliced intron and non-spliced intron within gus gene on cDNA of six transgenic lines relative to the housekeeping gene $(E f \alpha l)$ as a reference gene by different amplification cycles $(25,30,35$, and 40$)$.

\begin{tabular}{|c|c|c|c|c|c|c|c|c|c|c|c|c|c|c|c|c|}
\hline \multirow[t]{2}{*}{ Cycles } & \multicolumn{6}{|c|}{ Relative Quantity for Gus-intron plus } & \multirow[t]{2}{*}{ Mean } & \multicolumn{6}{|c|}{$\begin{array}{c}\text { Relative Quantity for } G u s-\text { intron } \\
\text { minus }\end{array}$} & \multirow[t]{2}{*}{ Mean } & \multirow[t]{2}{*}{$\begin{array}{l}\text { Un-splicing } \\
\%\end{array}$} & \multirow[t]{2}{*}{$\begin{array}{c}\text { Splicing } \\
\%\end{array}$} \\
\hline & 1 & 2 & 3 & 4 & 5 & 6 & & 1 & 2 & 3 & 4 & 5 & 6 & & & \\
\hline 25 & 0.24 & 0.11 & 0.59 & 0.21 & 0.44 & 0.46 & 0.342 & 0.74 & 0.91 & 0.39 & 0.81 & 0.54 & 0.56 & 0.658 & 34.2 & 65.8 \\
\hline 30 & 0.41 & 0.19 & 0.11 & 0.19 & 0.03 & 0.01 & 0.157 & 0.61 & 0.79 & 0.91 & 0.79 & 0.99 & 0.98 & 0.843 & 15.7 & 84.3 \\
\hline 35 & 0.29 & 0.21 & 0.09 & 0.11 & 0.01 & 0.06 & 0.128 & 0.69 & 0.81 & 0.89 & 0.91 & 0.97 & 0.95 & 0.872 & 12.8 & 87.2 \\
\hline 40 & 0.36 & 0.19 & 0.26 & 0.14 & 0.02 & 0.01 & 0.163 & 0.66 & 0.79 & 0.76 & 0.84 & 0.99 & 0.98 & 0.837 & 16.3 & 83.7 \\
\hline
\end{tabular}

Table 3. Relative quantification of transcripts of spliced intron and non-spliced intron within GFP gene on cDNA of six transgenic lines relative to the housekeeping gene $(\mathrm{EF} 1 \alpha)$ as a reference gene by different amplification cycles $(25,30,35$, and 40$)$.

\begin{tabular}{|c|c|c|c|c|c|c|c|c|c|c|c|c|c|c|c|c|}
\hline \multirow[t]{2}{*}{ Cycles } & \multicolumn{6}{|c|}{ Relative Quantity for $G F P$-intron } & \multirow[t]{2}{*}{ Mean } & \multicolumn{6}{|c|}{$\begin{array}{c}\text { Relative Quantity for } G F P \text {-intron } \\
\text { minus }\end{array}$} & \multirow[t]{2}{*}{ Mean } & \multirow{2}{*}{$\begin{array}{c}\text { Un- } \\
\text { splicing } \\
\%\end{array}$} & \multirow{2}{*}{$\underset{\%}{\text { Splicing }}$} \\
\hline & 1 & 2 & & $\begin{array}{r}\text { lus } \\
4\end{array}$ & 5 & 6 & & 1 & 2 & $\operatorname{mir}_{3}$ & & 5 & & & & \\
\hline 25 & 0.34 & 0.06 & 0.29 & 0.21 & 0.09 & 0.41 & 0.233 & 0.64 & 0.96 & 0.69 & 0.81 & 0.89 & 0.61 & 0.767 & 23.3 & 76.7 \\
\hline 30 & 0.41 & 0.34 & 0.11 & 0.19 & 0.11 & 0.54 & 0.283 & 0.61 & 0.64 & 0.91 & 0.79 & 0.91 & 0.44 & 0.717 & 28.3 & 71.7 \\
\hline 35 & 0.44 & 0.11 & 0.01 & 0.11 & 0.02 & 0.61 & 0.217 & 0.54 & 0.91 & 0.97 & 0.91 & 0.96 & 0.41 & 0.783 & 21.7 & 78.3 \\
\hline 40 & 0.36 & 0.24 & 0.21 & 0.14 & 0.11 & 0.14 & 0.20 & 0.66 & 0.74 & 0.81 & 0.84 & 0.91 & 0.84 & 0.80 & 20 & 80 \\
\hline
\end{tabular}

revealed that the non-spliced transcripts were $34.2 \%, 15.7 \%, 12.8 \%$ and 16.3 $\%$ whereas, the spliced transcripts were $65.8 \%, 84.3 \%, 87.2 \%$, and $80 \%$ at 25 , 30,35 and 40 cycles respectively. While, the ratio of non-spliced $g f p$ transcripts was $23.3 \%, 28.3 \%, 21.7 \%$ and $20 \%$ respectively and the percentage of spliced transcripts was $76.7 \%, 71.7 \%, 78.3 \%$ and $80 \%$ at $25,30,35$ and 40 cycles, respectively. The results pointed out that the gene expression of the transcripts (without intron) in which their intron was spliced out, was higher than those of non-spliced transcripts (with intron) i.e. the both introns inside gus and $g f p$ were partially and not completely spliced out of the transcripts.

It has been reported that variation in expression levels can depend on many factors: (1) The characteristics and sequence of the intron used: In plants 
enhancement of gene expression is observed only in the more GC-rich (monocot) genomes (Vain et al., 1996). (2) The location and orientation in the transcript: Callist et al. (1987). Mascarenhaset al. (1990) and Clancy et al. (1994) reported that introns must be located within the transcribed sequences and in their normal orientation to stimulate expression. Bourdon et al. (2001) found that the position and sequence of an intron have remarked effects on expression levels. (3) The nature of other sequences in the construct (Bourdon et al., 2001). (4) The celltype and species in which the construct is expressed (Clancy and Hannah,2002). However, the mechanism by which introns can enhance transgene expression remains enigma, and it has been suggested that more than one mechanism of intron-mediated enhancement may exist (Christie et al., 2011). Insertion of the introns inside the open coding region of the reporter gene were exposed to improve gene expression (Tanaka et al, 1990). However, increasing of gene expression by introns is not a common phenomenon since some naturally occurring genes do not include introns and are expressed powerfully.

In the present study, the expression of $g u$ s and $g f p$ genes might linked to the process of splicing and not to a particular intron sequence or the partial splicing may due to splicing signals within the sequences of the both introns. In conclusion, in spite of the incomplete splicing of the IV2 second intron of the potato $S T-L S 1$ gene and frist intron of a castor bean gene for catalase, the expression of gus and $g f p$ genes was not affected. Where, it was ranged from $71.7 \%$ to $80 \%$ and from 65.8 to 87.2 for the gus and $g f p$, respectively in the spliced introns. Therefore, the expression of the non-spliced gus and $g f p$ introns was much lower than those of spliced ones.

Conclusively, in the present study, the expression of gus and gfp genes might linked to the process of splicing and not to a particular intron sequence or the partial splicing may due to splicing signals within the sequences of the both introns. In conclusion, in spite of the incomplete splicing of the IV2 second intron of the potato $S T-L S-1$ gene and fristintron of a castor bean gene for catalase, the expression of $g u s$ and $g f p$ genes was not affected. Where, it was ranged from $71.7 \%$ to $80 \%$ and from 65.8 to 87.2 for the gus and $g f p$, respectively in the spliced introns. Therefore, the expression of the non-spliced gus and $g f p$ introns was much lower than those of splicedones.

\section{REFERENCES}

An, G.E.P., Mitra, A. and S.B. Ha (1988). Binary Vectors. In: Gelvin, S.B., Ed., Plant Molecular Biology Manual, Martinus Nijhoff, Dordrecht, 1- 19. 
Barghchi, M., Turgut, K., Scott, R. and J. Draper (1995). High- frequency A grobacterium- mediated transformation of Arabidopsis thaliana ecotypes "C24" and "Landsbergerecta." J. Plant Growth Reg. 14:61-67.

Bartlett, J.G., Snape, J.W. and W.A. Harwood (2009). Intron-mediated enhancement as a method for increasing transgene expression levels in barley. Plant Biotechnol. Journal, 7: 856-866.

Bourdon, V., Harvey, A. and D.M. Lonsdale (2001). Introns and their positions affect the translational activity of mRNA in plant cells. EMBO Rep., 2: 394-398.

Buchman, A.R. and P. Berg (1988). Comparison of intron-dependent and intron-independent gene expression. Mol. Cell. Biol., 8: 4395-4405.

Callis, J., Fromm, M. and V. Walbot (1987). Introns increase gene expression in cultured maize cells. Genes Dev., 1: 1183-1200.

Chee, P.P., Klassy, R.C. and J.L. Slightom (1986). Expression of a bean storage protein phaseolin "minigene" in foreign plant tissues. Gene, 41: 47-57.

Christie, M., Larry, J. Croft, and B.J. Carroll (2011). Intron splicing suppresses RNA silencing in Arabidopsis. The Plant Journal , 68: 159- 167.

Clancy, M., Vasil, V., Hannah, L.C. and I.K. Vasil (1994). Maize Shrunken-1 intron and exon regions increase gene expression in maize protoplasts. Plant Sci., 98: 151-161.

Clancy, M. and L.C. Hannah (2002). Splicing of the maize Sh1 first intron is essential for enhancement of gene expression, and a T-rich motif increases expression without affecting splicing. Plant Physiol., 130: 918-929.

Depicker, S., Stachel, P., Dhaese, P. and Z.H.M. Goodman (1982). A Nopaline synthase: transcript mapping and DNA sequence J. Mol. Appl. Genet., 1: 561-573.

Donath, M., Mendel, R., Cerff, R. and W. Martin (1995). Introndependent transient expression of the maize GapA1 gene. Plant Mol. Biol., 28: 667- 676.

Eckes, P., Rosahl, S., Schell, J. and L. Wilmitzer (1986). Isolation and characterization of a light-inducible, organ-specific gene from potato (Solanum tuberosum) and analysis of its expression after tagging and transfer into tobacco and potato shoots. Mol. Gen. Genet., 205: 14-22.

Fladung M (1999). Gene stability in transgenic aspen (Populus). I. Flanking DNA sequences and T-DNA structure. Molecular and General Genetics, 260: 574-581.

Hobbs SLA, Kpodar P, Delong CMO (1990). The effect of T-DNA copy number, position and methylation on reporter gene expression in tobacco transformants. Plant Molecular Biology, 15: 851-864. 
Johnson, A.A.T., Hibberd, J.M., Gay, C., Essah, P.A., Haseloff, J., Tester, M. and E. Guiderdoni (2005). Spatial control of transgene expression in rice (Oryza sativa L.) using the GAL4 enhancer trapping system, Plant Journal, 41: 779-789.

Ibrahim, A.F., Watters, J.A., Clark, G.P., Thomas, C.J., Brown, J.W. and C.G. Simpson (2001). Expression of intron-containing GUS constructs is reduced due to activation of a cryptic $5^{\prime}$ splice site. Mol. Genet. Genomics, 265: 455-460.

Khidr, Y.A. and I.M. Nasr (2012). Improvement of genetic transformation and plant regeneration via suspension cultures in Cucurbitaceae family. Egypt J Genet. Cytol., 41: 1-18.

Ma, H., Lin, Z. and Y. Hu (2011). The modified castor bean catalase intron is incompletely spliced in tobacco and Arabidopsis. Plant Science, 181: 188-194.

Maqbool S.B., Christou P. (1999). Multiple traits of agronomic importance in transgenic indica rice plants: analysis of transgene integration patterns, expression levels and stability. Molecular Breeding, 5: 471-480.

Mascarenhas, D., Mettler, I.J., Pierce, D.A. and H.W. Lowe (1990). Intron- mediated enhancement of heterologous gene expression in maize. Plant Mol. Biol., 15: 913-920.

McCullough, A.J., Lou, H. and M.A. Schuler (1993). Factors affecting authentic 5' splice site selection in plant nuclei. Mol. Cell Biol., 13: 13231331.

Murashige, T. and F. Skoog (1962). A revised medium for rapid growth and bio-assays with tobacco tissue cultures. Physiol. Plant, 15: 473497.

Narasimhulu, S.B., Deng, X.B., Sarria, R. and S.B. Gelvin (1996). Early transcription of Agrobacterium T-DNA genes in tobacco and maize. Plant Cell, 8: 873-886.

Odell, J.T., Nagy, F. and N.-H Chua (1985). Identification of DNA sequences required for activity of the cauliflower mosaic virus $35 \mathrm{~S}$ promoter. Nature, 313: 810-812.

Ohta, S., Mita, S., Hattori, T. and K. Nakamura (1990). Construction and expression in tobacco of a glucuronidase (Gus) reporter gene containing an intron within the coding sequence, Plant Cell Physiol, 31: 805-813.

Rempel, H.C. and L.M. Nelson (1995). Analysis of conditions for Agrobacterium-mediated transformation of tobacco cells in suspension. Transgenic Res., 4: 199-207. 
Rose, A.B. (2004). The effect of intron location on intron-mediated enhancement of gene expression in Arabidopsis, Plant Journal, 40: 744-751.

Sinibaldi, R.M. and I.J. Mettler (1992). Intron Splicing And Intron-Mediated Enhanced Expression In Monocots. In: Cohn WE, Moldave K, editors.

Tanaka, A., Mita, S., Ohta, S., Kyozuka, J., Shimamoto K. and K. Nakamura (1990). Enhancement of foreign gene expression by a dicot intron in rice but not in tobacco is correlated with an increased level of mRNA and an efficient splicing of the intron. Nucleic Acids Res., 18: 6767- 6770.

Vain, P., Finer, K.M., Engler, D.E., Pratt, R.C. and J.J. Finer (1996). Intron- mediated enhancement of gene expression in maize (Zea mays L.) and bluegrass (Poapratensis L.) Plant Cell Rep. 15: 489-494.

Vancanneyt, G., Schmidt, R., Oconnor-Sanchez, A., Willmitzer, L., and M. Rocha-Sosa (1990). Construction of an intron-containing marker gene: Splicing of the intron in transgenic plants and its use in monitoring early events in Agrobacterium-mediated plant transformation. Mol. Gen. Genet., 220: 245-250.

Wesley, S.V., Helliwell, C.A., Smith, N.A., Wang, M., Rouse, D.T., Liu, Q., Gooding, P.S., Singh, S.P., Abbott, D., Stoutjesdijk, P.A., Robinson, S.P., Gleave A.P., Green, A.G. and P.M. Waterhouse (2001). Construct design for efficient, effective and high-throughput gene silencing in plants. Plant Journal, 27: 581-590.

$$
\begin{aligned}
& \text { التحليل الوظيفى للانترونات فى تأثيرها على تعبيز الجين } \\
& \text { المحول فى النبات. }
\end{aligned}
$$

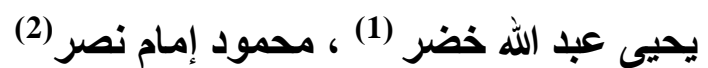

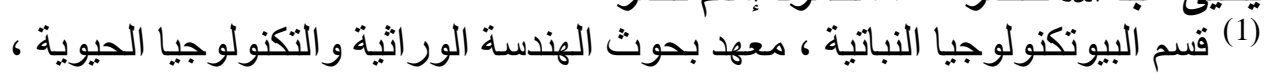

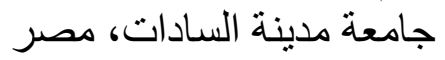

$$
\begin{aligned}
& \text { (2) قسم البيولوجيا الجزيئية ، معهد بحوث مدينة الهندسة الور اثية و التكنولوجيا الحيوية ، مهية }
\end{aligned}
$$

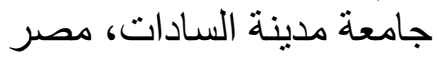

$$
\begin{aligned}
& \text { تحتوي معظم الجينات النباتية على تتابعات بينية تسمى انترونات و التي يتم } \\
& \text { نسخها إلى ال RNA الرسول الاولى (الغير ناضج) قبل إز التها في وقت لاحق عن التهات }
\end{aligned}
$$

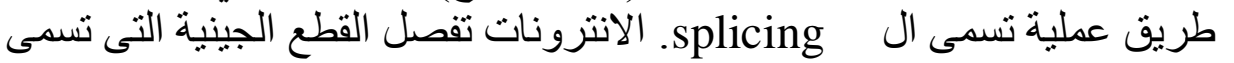

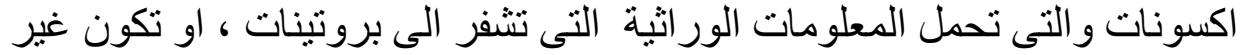

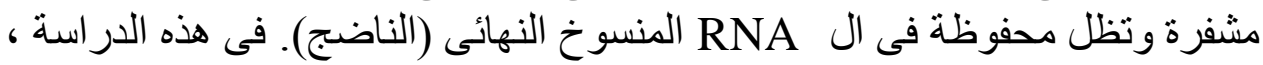


تم قياس مستوى النسخ للانترونات التى تم از التها وكذلك التى ظلت

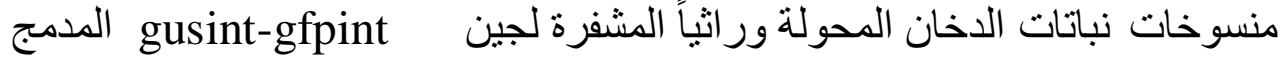
و الذى ينظم نسخه ال CaMV 35S كقائد. تم تتفيذ تحليل عملية النسخ بو اسطة

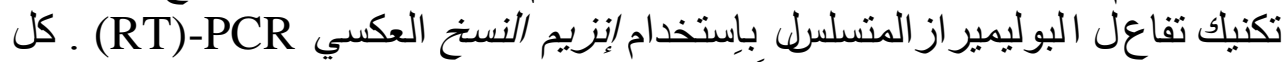

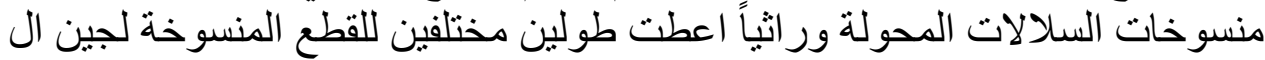
. gus gfp اوضحت النتائج ان التعبير الجينى للمنسوخات التى تمت از الت الت نيتروناتها كان

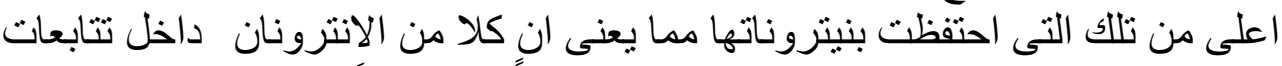

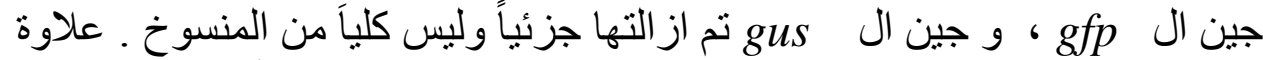

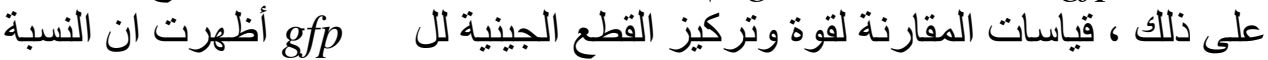

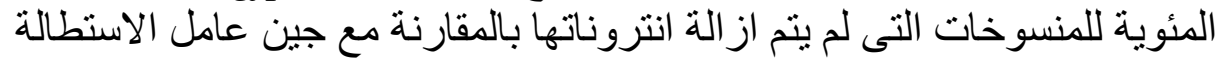

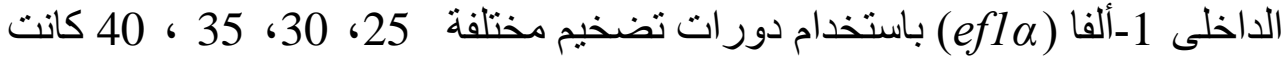

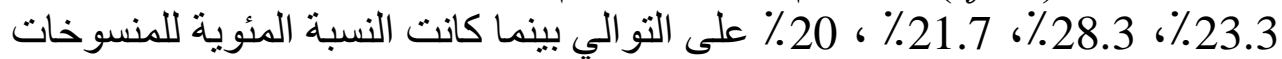

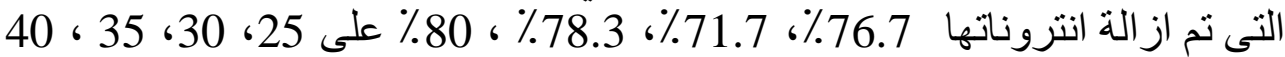

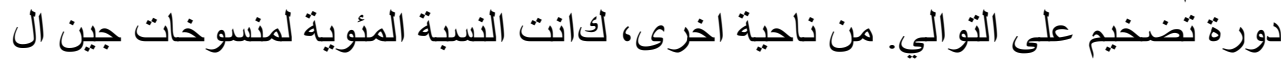

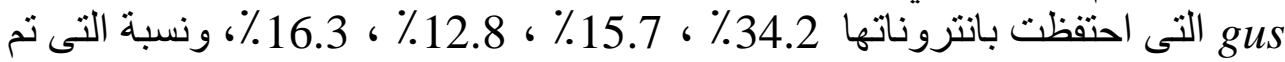

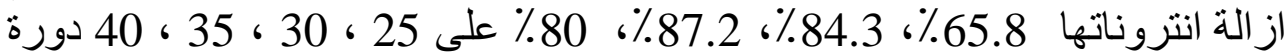

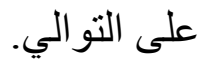

التوصية: في در استنا،قد يكون التعبير الجينى لجين اتال gus وgfp مرتبط بعملية ال splicing

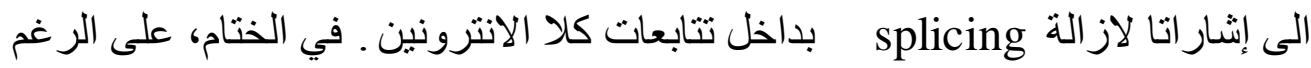

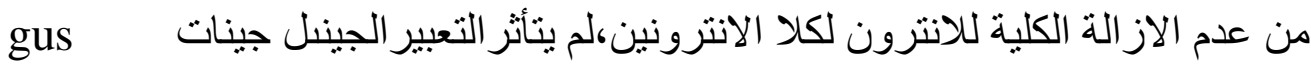

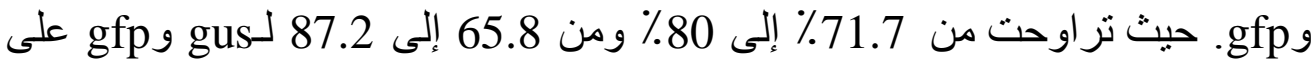

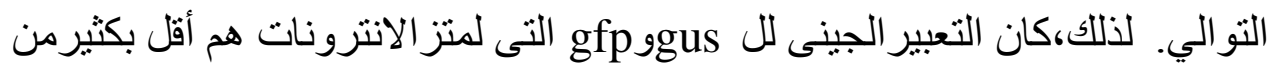
تعبير ات من تلكالتى ازيلت. 